\title{
Comparison of Post-transplant Cyclophosphamide Containing Immunosuppressive Regimen with Standard Immunosuppressive Regimen in Allogeneic Stem Cell Transplantation from Matched Sibling Donor
}

\author{
Tam Uyumlu Kardeş Donörden Yapılan Nakillerde Post-transplant Siklofosfamid Içeren \\ Immünosüpresif Rejimin Standart Immünosüpresif Rejimle Karşılaştırılması
}

\author{
(D) Osman KARA ${ }^{1}$, (D) Tayfun ELIBOL 2 \\ ${ }^{1}$ Bahçeşehir University Faculty of Medicine, Department of Hematology, istanbul, Turkey \\ ${ }^{2}$ Göztepe Prof. Dr. Süleyman Yalçın City Hospital, Clinic of Hematology, Istanbul, Turkey
}

\begin{abstract}
Aim: Allogeneic stem cell transplantation (ASCT) is the only treatment that can cure most of malignant hematological diseases with the risk of some serious complications such as graft-versus-host disease (GVHD). GVHD can be got under control with post-transplant cyclophosphamide even in patients with haploidentical stem cell transplants. Here, we aimed to compare the effectiveness of post-transplant cyclophosphamide on GVHD with standard immunosuppressive therapy.

Materials and Methods: Patients with high-risk hematologic malignancies, who received ASCT from human leukocyte antigen-matched sibling donors, were studied. Patients in the post-transplant cyclophosphamide group also used tacrolimus and mycophenolate mofetil; on the other side, standard immunosuppressive treatment with cyclosporine and methotrexate was used. The primary endpoint of the study was to compare the severe acute GVHD rate between the groups.

Results: A total of 40 patients were included in the study. While severe (grade 3-4) GVHD was seen in three patients in the methotrexate-cyclosporin group, it was not seen in any patient in the post-transplant cyclophosphamide group. Also, 10th-month progress-free survival and overall survivals were $78.8 \%$ and $93.3 \%$ vs 56\% and $72 \%$ in the post-transplant cyclophosphamide group and methotrexate-cyclosporin group, respectively.

Conclusion: Cyclophosphamide can be the cheapest, most applicable, and clinically effective treatment in GVHD prophylaxis.
\end{abstract}

Keywords: Allogeneic stem cell transplant, graft-versus-host disease, cyclophosphamide

ÖZ

Amaç: Allojenik kök hücre nakli (AKHN), birçok hematolojik malignite için, graft-versus-host hastalığı (GVHH) gibi bazı hayatı tehdit edici risklerine rağmen halen tek küratif tedavi yöntemidir. GVHH post-transplant siklofosfamid uygulamasıyla birlikte haploidentik kök hücre nakli yapılan hastalarda dahi kontrol altına alınabilmektedir. Çalışmamızın amacı da tam uyumlu kardeş donörden yapılan nakillerde post-transplant siklofosfamid kullanımının GVHH üzerine olan etkinliğini standart immünosüpresif tedaviyle karşılaştırmaktır.

Gereç ve Yöntem: Yüksek riskli hematolojik malignite tanısı olup tam uyumlu kardeş donörden AKHN yapılan hastalar çalışmaya alındı. Posttransplant siklofosfamid tedavisi alan hastalar, immünosüpresif tedavi olarak ayrıca takrolimus ve mikofenolat mofetil aldı; diğer kolda ise hastalar metotreksat ve siklosporin ile standart immünosüpresif tedavi aldı. Çalışmanın primer sonlanım noktası şiddetli akut GVHH gelişimi sıklığı olarak belirlendi. 
Bulgular: Çalışmaya toplam 40 hasta alındı. Standart immünosüpresif kolunda yalnızca 3 hastada şiddetli (grade 3-4) GVHH görülürken, posttransplant siklofosfamid alan grupta hiç görülmedi. Hastaların 1 yıllık progresyonsuz sağkalım ve genel sağkalım oranları standart immünosüpresif tedavi alanlar için \%54 ve \%62, post-transplant siklofosfamid alan hastalar için \%78,8 ve \%93,3 olarak izlendi.

Sonuç: Post-transplant siklofosfamid, ucuz, kullanılabilir ve klinik olarak etkili bir GVHH profilaksi ajanı olarak kök hücre naklinde kullanılabilir.

Anahtar Kelimeler: Allojenik kök hücre nakli, graft-versus host disease, siklofosfamid

\section{INTRODUCTION}

Allogeneic stem cell transplantation (ASCT) continues to be the only treatment modality that can cure most malignant hematological disorders even with high rates of complications such as acute and chronic graft-versus-host disease (GVHD). Some investigational manipulations, such as in vitro/in vivo T-cell depletion before transplant, T-cell repletion with cyclophosphamide (Cy) after transplant or long-term immunosuppression with cyclosporine A (CysA), mycophenolate mofetil (MMF), methotrexate (MTX), or antithymocyte globuline, can be used to maintain graft survival possibility and also decrease GVHD.

In vivo/In vitro T-cell depletion before ASCT is not a viable strategy in most transplantation centers due to technical and financial difficulties. For the first time in 2008, a group of experienced researchers from John Hopkins University reported that they successfully used post-transplant cyclophosphamide (PTCy) in haploidentical ASCT for T-cell repletion'. Especially the decrease in the frequency of severe acute and chronic GVHD (cGVHD) (grade 3-4) and the increase in GVHD free survival rates (HOVON96) ${ }^{2}$ obtained with post-transplant high dose Cy $(50 \mathrm{mg} / \mathrm{kg} / \mathrm{d}$, on days +3 and +4$)$, which is widely applied in human leukocyte antigen (HLA) haploidentical stem cell transplantation (SCT) cases, paved the way for the application of PTCy in HLA-matched ASCTs.

In this study, we aimed to show the results of prophylactic PTCy use on GVHD in patients who underwent ASCT from HLA full-matched related donors (MRD), and to compare these results with conventional IST.

\section{MATERIALS AND METHODS}

This is a cross-sectional cohort study and designed from information obtained from electronic/hard-copy files of patients followed up in a single SCT center. For all patients in the study, ASCT was performed from a related donor with full compatibility of HLA-A, $-B_{1}-C_{1}-D R B 1$, and -DQB1 alleles. The primary endpoint of the study was to show the rate of severe (grade 3-4) acute GVHD (aGVHD) defined by the International Bone Marrow Transplant Registry criteria ${ }^{3}$. Secondary end points were transplant-related mortality (TRM), graft failure (primary or secondary), progression-free survival (PFS), overall survival (OS), cytomegalovirus (CMV) reactivation, opportunistic infections, and cGVHD defined by National Institutes of Health (NIH) consensus criteria.

The study was approved by the Local Institutional Review Board and Ethics Committee and was conducted in accordance with the Helsinki Declaration of 1975. Approval for the study was obtained from the Local Ethics Committee of İstanbul Medeniyet University (decision no: 2021/0018, date: 13.01.2021).

\section{Conditioning Regimens and Immunosuppressive Treatment}

Fludarabine and busulfan-based conditioning regimens were used for myeloid malignancies, while fludarabine-TBI-based regimens were used in lymphoid malignancies.

GVHD prophylaxis regimens were as follows: for patients who received PTCy, it was given at $50 \mathrm{mg} / \mathrm{kg} /$ day iv on day +3 and +4 with MESNA. Tacrolimus at a dose of $0.03 \mathrm{mg} / \mathrm{kg} /$ day $24 \mathrm{~h}$ infusion was started on day +5 , targeting through the plasma levels between 5 and $15 \mathrm{ng} / \mathrm{mL}$ and changed to oral form on day +14 and continued at least for 3 months. MMF at a dose of 15 $\mathrm{mg} / \mathrm{kg}$ three times a day (total $45 \mathrm{mg} / \mathrm{kg} /$ day) was also started on day +5 and continued till $+28^{\text {th }}$ day. For patients who used MTX and CysA as prophylaxis, MTX was given at a dose of 15 $\mathrm{mg} / \mathrm{m}^{2} /$ day on day +1 and at a dose of $10 \mathrm{mg} / \mathrm{m}^{2} /$ day on days $+3,+6$, and +11 . Calcium folinate was administered on days $+2,+4,+7$, and +12 especially to prevent mucositis and renal

\section{Table 1. Immunosuppressive regimens}


toxicities of MTX. CysA was started at a dose of $1.8 \mathrm{mg} / \mathrm{kg} /$ day in two daily doses intravenously on day +5 , targeting through the CysA plasma level of $200-400 \mathrm{ng} / \mathrm{mL}$ and continued as oral therapy for at least six months after transplantation (Table 1).

\section{Supportive Care}

Ganciclovir and valaciclovir were given to all patients for CMV prophylaxis. CMV DNA polymerase chain reaction analysis follow-up was performed according to related guidelines and CMV activation was defined as copy number of over 1,000 copies/mL or more in two consecutive measurements.

All patients received prophylaxis for bacterial and fungal infections as well as for Pneumocystis jirovecii according to related guidelines. Time to neutrophil engraftment was defined as the first of three consecutive days with an absolute neutrophil count $>0.5 \times 10^{9} / \mathrm{L}$ after transplant, and time to platelet engraftment was defined as a platelet count of $20 \times 10^{3} / \mathrm{L}$ with no transfusion need during the preceding 7 days.

Lymphocyte recovery was defined as the day that absolute lymphocyte count was $\geq 0.4 \times 10^{9} / \mathrm{L}$. While full chimerism was defined as 95\% of blood CD3+ cells are of donor origin, mixed chimerism was defined as 66-94\% of CD3+ cells are of donor origin, and non-chimerism was defined as $<65 \%$ of CD3+ cells are of donor origin in the host blood sample.

\section{Statistical Analysis}

The study population was described using frequencies with associated percentages for qualitative data and using median and range for quantitative data. The difference in blood levels in the two groups was compared using the Mann-Whitney $\mathrm{U}$ test comparing continuous data. The chi-square tests and Fisher's exact tests were used to compare categorical variables. $\mathrm{OS}$ and PFS were started from donor CD34+ stem cell infusion. Time elapsed between the day of transplantation and death or last contact was used to estimate OS. PFS was calculated as the time from the first day of the transplantation to progression, death of any cause, or last contact. The Kaplan-Meier curves were generated for survival analyses and the Breslow tests were used to assess differences in OS and PFS between study groups. A $p$ value $\leq 0.05$ was considered statistically significant. The IBM Statistical Package for the Social Sciences system version 25 was used for all analyses.

\section{RESULTS}

\section{Demographic Data}

Between 2016 and 2020, we enrolled 15 patients in the PTCy group and 25 patients in the MTX-CysA group. There was no difference between the two groups in terms of age, gender, and disease distribution, or treatment preferences. Characteristics of the patients are given in Table 2 .

\section{Engraftment and Immune Reconstitution}

The median time to neutrophil engraftment for the PTCy and the MTX-CysA groups were 14 days and 15 days, respectively $(p=0.94)$. The median time to platelet engraftment was 21 days for the PTCy group and 20 days for the MTX-CysA group

Table 2. Patients characteristics

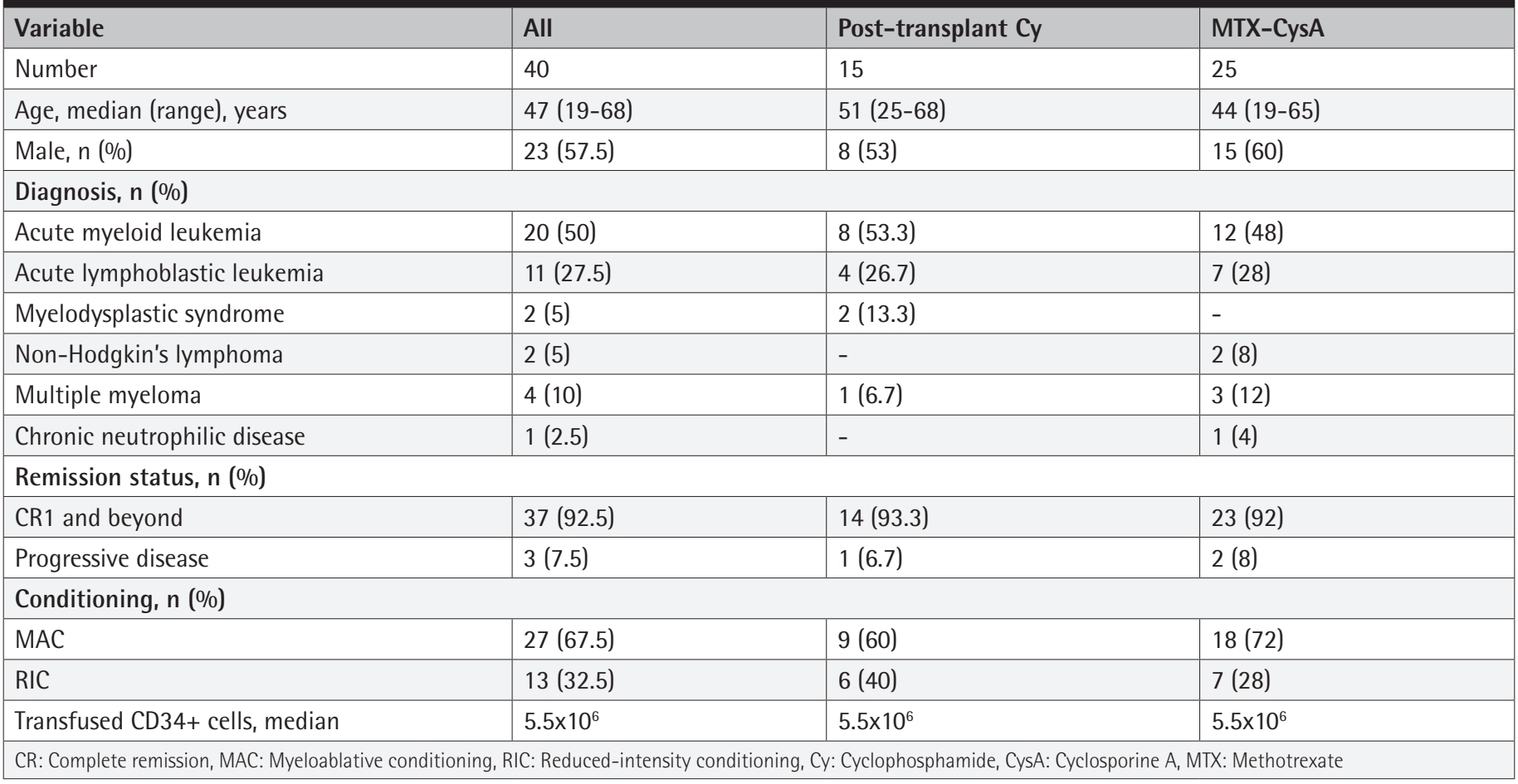


$(p=0.99)$. Lymphocyte recovery time was 29.5 days and 20 days, respectively $(p<0.001)$. Primary graft failure was seen only in one patient in the PTCy group (6.7\%), and in five patients $(20 \%)$ in the MTX-CysA group ( $p=0.381)$; secondary graft failure was observed in three patients and four patients, respectively $(p=0.618)$. Donor chimerism could not be assessed in one patient in the MTX-CysA group due to early mortality. Full donor chimerism was achieved in all except one patient in the PTCy group (93.3\%), and 21 patients (87.5\%) in the MTXCysA group at day $+30(p=1)$. Three patients in the MTX-CysA group, who had full-chimerism at day +30 , lost full chimerism in long-term follow-up (Table 3).

\section{Infections and Complications}

Febrile neutropenia was observed in five patients (33.3\%) and 15 patients $(60 \%)$ in the PTCy group and the MTX-CysA group, respectively $(p=0.191)$. All patients were treated with appropriate antibiotics and complete control of infection was achieved, but one patient in the MTX-CysA group died from sepsis on day +29 . Both patients and donors had positive CMV serology before ASCT. CMV reactivation was seen in four patients $(26.7 \%)$ and 15 patients (60\%) for the PTCy group and the MTX-CysA group, respectively $(p=0.06)$. In all patients, preemptive therapy with ganciclovir was successful. Frequency of hemorrhagic cystitis in both groups was similar (Table 4).

\section{Graft-Versus-Host Disease}

Grade 2-4 aGVHD was observed in two (13.3\%) and seven (28\%) of the patients in the PTCy and MTX-CysA groups, respectively. In terms of the primary endpoint of the study, there was no statistical difference between the groups. Grade 3-4 GVHD was not seen in any patient in the PTCy group and was seen in three patients in the MTX-CysA group (12\%) $(p=0.279)$. In the PTCy group, one patient had grade 1 skin and one patient had grade 1 liver GVHD, and one patient had grade 2 liver GVHD. In the MTX-CysA group, one patient had grade 1, four patients had grade 2, and one patient had grade 3 skin GVHD; one patient had both grade 3 skin and liver GVHD, one patient had both grade 3 skin and gut GVHD.

cGVHD was not evaluated in patients who progressed or died within the first 100 days of ASCT. It was seen in three patients $(21.4 \%)$ in the PTCy group and five patients $(25 \%)$ in the MTXCysA group $(\mathrm{p}=1)$ (Table 4).

\section{Survival Outcomes}

The median follow-up period for the entire population was 10.6 months. PFS on the $100^{\text {th }}$ day of the ASCT to evaluate early recurrence was $93.3 \%$ in the PTCy group and $80 \%$ in the MTX-CysA group; PFS on the $10^{\text {th }}$ month of the ASCT was $78.8 \%$ in the PTCy group but 56\% in the MTX-CysA group $(p=0.18)$ (Figure 1). OS on the $100^{\text {th }}$ day of the ASCT to evaluate

\section{Table 3. Transplant outcomes}

\begin{tabular}{|l|l|l|l|}
\hline Variable & Post-transplant Cy & MTX-CysA & $\mathbf{p}$ \\
\hline Neutrophil recovery, median (range), days & $14(11-28)$ & $15(9-41)$ & 0.94 \\
\hline Platelet recovery, median (range) days & $21(14-42)$ & $20(12-141)$ & 0.99 \\
\hline Lymphocyte recovery, median (range) days & $29.5(17-42)$ & $20(11-36)$ & $<0.001$ \\
\hline Full donor chimerism on day 90, n (\%) & $14(93.3)$ & $21(87.5)$ & 1 \\
\hline 1-year PFS, \% & 78.8 & 52 & 0.18 \\
\hline 1-year OS, \% & 93.3 & 64 & 0.2 \\
\hline Median follow-up (range), months & $9.8(5-17.3)$ & $22.6(0.97-84.8)$ & 0.12 \\
\hline OS: Overall survival, PFS: Progress-free survival, Cy: Cyclophosphamide, CysA: Cyclosporine A & \\
\hline
\end{tabular}

Table 4. Transplant complications

\begin{tabular}{|c|c|c|c|}
\hline Variable & Post-transplant Cy & MTX-CysA & $\mathbf{p}$ \\
\hline Number & 15 & 25 & \\
\hline aGVHD 2-4, n (\%) & $2(13.3)$ & $7(28)$ & 0.44 \\
\hline cGVHD 2-4, n (\%) & $3(21.4)$ & $5(25)$ & 1 \\
\hline Hemorrhagic cystitis, n (\%) & $1(6.7)$ & $3(12)$ & 1 \\
\hline Incidence of poor graft function, $\mathrm{n}(\%)$ & $1(16.7)$ & $5(20)$ & 0.38 \\
\hline Treatment-related mortality, n (\%) & $0(0)$ & $4(16)$ & 0.28 \\
\hline
\end{tabular}


early mortality was 100\% in the PTCy group and $88 \%$ in the MTX-CysA group; OS on the $10^{\text {th }}$ month of the ASCT was $93.3 \%$ in the PTCy group and $72 \%$ in the MTX-CysA group $(p=0.2)$ (Figure 2). Treatment-related mortality was not seen in the PTCy group and was seen in four patients (16\%) in the MTXCysA group ( $p=0.28$ ) (Table 4).

\section{DISCUSSION}

In this retrospective cross-sectional study, we aimed to compare the clinical results of patients who received highdose $\mathrm{Cy}$ after allograft infusion and those who received MTX-CysA, with particular emphasis on GVHD. The use of tacrolimus for 3 months with PTCy is easier than the use of an immunosuppressive with a wide side effect profile such as cyclosporine for 6 months. As far as we know, this is the only

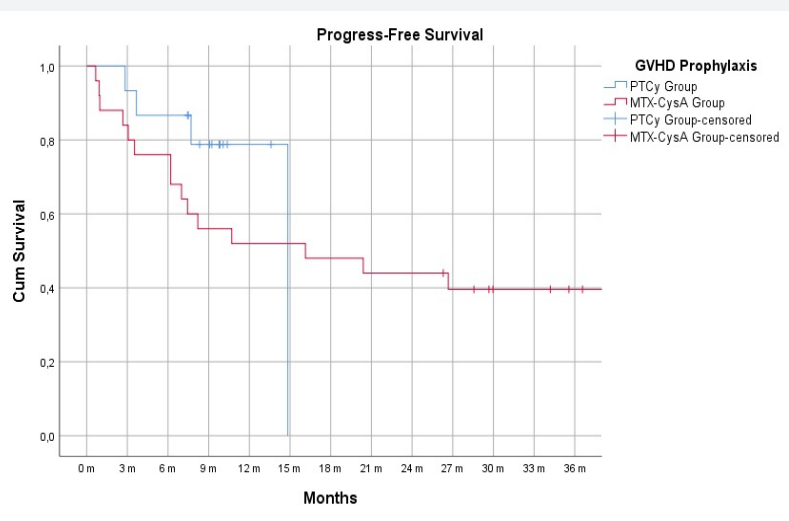

Figure 1. Comparison of progress-free survival of patients between the PTCy group and MTX-CysA group

MTX: Methotrexate, GVHD: Graft-versus-host disease, CysA: PTCY:

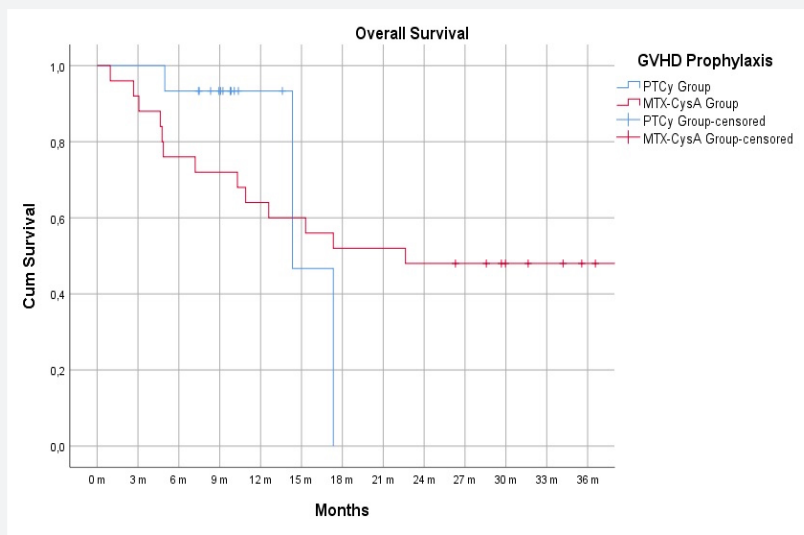

Figure 2. Comparison of overall survival of patients between the PTCy group and MTX-CysA group

MTX: Methotrexate, GVHD: Graft-versus-host disease, CysA: PTCy: study that compares patients who use PTCy and MTX-CysA for GVHD prophylaxis in HLA-matched sibling donors.

aGVHD was seen in two patients (13.3\%) in the PTCy group, while grade 3-4 aGVHD was not observed in any patient. In the MTX-CysA group, aGVHD was observed in $10(40 \%)$ patients $(p=0.44)$, while three of them $(12 \%)$ had grade $3-4$ aGVHD ( $p=0.27)$. Mielcarek et al. ${ }^{4}$ performed a study, in which characteristics of the study population were quite similar to those of our study, which they used Cy plus cyclosporin for GVHD prophylaxis. The rates of grade 2-4 and grade 3-4 aGVHD were $77 \%$ and $0 \%$, respectively. It has been shown that alloreactive T lymphocytes can be inhibited more with calcineurin inhibitors added to the PTCy; this explains why the frequency of aGVHD was lower in our study. In the studies of Luznik et al. ${ }^{6}$ and Kanakry et al. ${ }^{7}$, the frequency of grade 3-4 aGVHD was found 10-15\% in ASCT patients with HLAmatched related and unrelated donors receiving PTCy. It is slightly more than that of our study probably because we had fewer patients and we only included patients who underwent ASCT from HLA-matched sibling donors.

In a study conducted by Luznik et al. ${ }^{1}$ in 2008, after HLA haploidentical donor SCT, the frequency of CGVHD was reduced to $25 \%$ with the administration of a single dose of $\mathrm{Cy}$, and decreased to $5 \%$ with two doses of Cy. After the successful results of this study, both Luznik and et al. ${ }^{6}$ applied PTCy after HLA-matched donor-derived allogeneic transplant in 2010 and observed the rate of cGVHD as $10 \%$.

In our study, the frequency of cGVHD diagnosed according to the NIH criteria was $21.4 \%(n=3)$ in the patients in the PTCy group and 25\% $(n=5)$ in the MTX-CysA group.

In two large studies ${ }^{8,9}$ using the same PTCy regimen that we used for GVHD prophylaxis, they found aGVHD (grade 2-4 and grade $3-4)$ rates similar to our study $(27 \%, 19 \%$ grade $2-4$ and $2 \%, 4 \%$ grade $3-4$ aGVHD, respectively). cGVHD rates were about $16 \%$, which was also similar to our study. The incidence of CGVHD in our study was higher than other reported studies due to the use of RIC regimen in 40\% of patients in the PTCy group and the use of stem cells mobilized from peripheral blood $^{8,10}$.

Graft failure at day +30 post-transplant was observed in only one (6.7\%) patient in the PTCy group but in five patients in the MTX-CysA group (20\%) ( $p=0.38)$. Secondary engraftment failure was detected in three (20.1\%) patients in the PTCY group, usually due to the use of cytotoxic agents such as ganciclovir or linezolid. We thought that the main causes of primary engraftment failure in a patient in the PTCy group were patients' diagnosis (myelodysplastic syndrome) and RIC regimen. Graft failure was observed in only one out of 35 patients who received PTCY-MMF-TAC in the study of 
Carnevale-Schianca et al." which was due to $P$. aeruginosa septicemia. It was also found in one of 28 patients (3.6\%) in the study conducted by El Fakih et al. ${ }^{12}$. Full-chimerism rates were 93.3\% for the PTCy group and $87.5 \%$ for the MTX-CysA group, which are similar to the aforementioned studies of Carnevale-Schianca et al. ${ }^{11}$ and Mielcarek et al. ${ }^{4}$.

In our study, times to neutrophil and platelet engraftment were found to be similar in the PTCy and MTX-CysA groups (neutrophil recovery time 14 days and 15 days, $p$ value $=0.94$, platelet recovery time 21 days and 20 days, $p$ value $=0.98$, respectively). Similar results were found for neutrophil and platelet recovery times in the study by Mielcarek et al. ${ }^{4}$ (neutrophil recovery time 14 days and platelet recovery time 19 days).

In our study, lymphocyte recovery time after transplantation was 20 days in the MTX-CysA group and 29.5 days in the PTCy group $(p<0.0001)$. Leo et al. ${ }^{13}$ also showed that the absolute lymphocyte count was found as $440 /$ microliter on the $30^{\text {th }}$ day after transplantation and $>700 /$ microliter on the $60^{\text {th }}$ day, similar to our study. In addition, protection of the immune reconstitution and immune-defense mechanism against bacterial agents with PTCy was also observed in our study. The frequency of febrile neutropenia was $33.3 \%(n=5)$ in the PTCy group and 60\% $(n=15)$ in the MTX-CysA group $(p=0.191)$.

CMV reactivation was observed in 26.7\% $(n=4)$ in the PTCy group and $60 \%(n=15)$ in the MTX-CysA group $(p=0.08)$. No CMV infection or end-organ damage developed in any of the patients in either group. The rate of CMV reactivation was 32\% in patients who received PTCy in a study by Leo et al. ${ }^{13}$, which is consistent with the data in our study. Although there was no statistically significant result in terms of CMV reactivation between the PTCY and MTX-CysA groups, a clinically significant decrease was observed in the PTCy group. The difference in CMV reactivation may gain statistical significance with the prolongation of the follow-up period.

In our study, the median follow-up time for all patients was 10.6 months (9.8 months vs 22.6 months). As of the $100^{\text {th }}$ day; OS rate was $100 \%$ and PFS rate was $93.3 \%$ in the PTCy group, and OS rate was $88 \%$ and PFS rate was $80 \%$ in the MTX-CysA group. In the $10^{\text {th }}$ month, while OS continued at the rate of $93.3 \%$ and PFS was $78.8 \%$ in the PTCy group, they were found to be $72 \%$ and $56 \%$ in the MTX-CysA group ( $p=0.2$ and $p=0.18)$, respectively. TRM was not observed in the PTCy group (0\%) during the observation period, while this rate was $16 \%(n=4)$ in the MTX-CysA group $(p=0.278)$. Luznik et al. ${ }^{6}$ examined patients who received high dose Cy after MRD/ MUD ASCT, they found OS 55\%, EFS 39\%, and TRM 17\% at the end of the second year. In a cohort study on 1,479 patients with acute leukemia (acute myeloid leukemia and acute lymphocytic leukemia) and patients transplanted from an
HLA-matched sibling/unrelated donor, the rates of two-year OS, PFS, relapse rate, and TRM were found $62 \%, 57 \%$, 28\%, and $14 \%$, respectively, with PTCy plus two immunosuppressive agents as GVHD prophylaxis ${ }^{14}$. In the previous studies, the two most important factors related to superior OS in patients who received PTCy for GVHD prophylaxis were the disease status (complete remission) at the time of transplant $(p<0.0001)$ and the addition of two immunosuppressive agents to $\mathrm{Cy}(\mathrm{p}=0.02)^{14}$. Although the median follow-up period of our study has not reached the second year, it seems to be similar or better than the results of other studies.

\section{Study Limitations}

Our study had many limitations. The design of our study was retrospective, with an inadequate number of patients in both groups and the shorter median follow-up period of the patients in the PTCy group compared to the other. Also, the distribution of conditioning regimens or disease subgroups was not same in both groups. So, we could not compare the difference between myeloablative and non-myeloablative regimens. The patients in our study will be followed for a minimum of two years and the results obtained will be added to the literature in light of current information.

\section{CONCLUSION}

High-dose PTCy, which has been used successfully in GVHD prophylaxis in HLA haploidentical ASCT patients for many years, can be even used successfully in GVHD prophylaxis after HLA matched (sibling/non-sibling) ASCT. In addition to its success in GVHD prophylaxis, it has been shown that it allows the discontinuation of other immunosuppressive therapies in the early period, contributes to the continuation of the graft-versus-disease effect, causes a possible decrease in CMV reactivation and febrile neutropenia, and thus has positive effects on PFS and OS. PTCy, compared to other GVHD prophylaxis, can be said to be the cheapest, most applicable, and most clinically effective one.

\section{Ethics}

Ethics Committee Approval: Approval for the study was obtained from the Local Ethics Committee of istanbul Medeniyet University (decision no: 2021/0018, date: 13.01.2021).

Informed Consent: Retrospective study.

Peer-review: Externally peer-reviewed.

\section{Authorship Contributions}

Surgical and Medical Practices: O.K., Concept: O.K., T.E., Design: O.K., T.E., Data Collection or Processing: O.K., Analysis or 
Interpretation: O.K., T.E., Literature Search: O.K., T.E., Writing: O.K., T.E.

Conflict of Interest: No conflict of interest was declared by the authors.

Financial Disclosure: The authors declared that this study received no financial support.

\section{References}

1. Luznik L, O'Donnell PV, Symons HJ, Chen AR, Leffell MS, Zahurak M, et al. HLA-haploidentical bone marrow transplantation for hematologic malignancies using nonmyeloablative conditioning and high-dose, posttransplantation cyclophosphamide. Biol Blood Marrow Transplant. 2008;14:641-50.

2. De Jong CN, Meijer E, Bakunina $K$, Nur E, van Marwijk Kooij M, R. de Groot $M$, et al. Post-Transplantation Cyclophosphamide after Allogeneic Hematopoietic Stem Cell Transplantation: Results of the Prospective Randomized HOVON-96 Trial in Recipients of Matched Related and Unrelated Donors. Blood. 2019;134(Supplement 1):1.

3. Rowlings PA, Przepiorka D, Klein JP, Gale RP, Passweg JR, Henslee-Downey PJ, et al. IBMTR Severity Index for grading acute graft-versus-host disease: retrospective comparison with Glucksberg grade. Br J Haematol. 1997;97:855-64.

4. Mielcarek M, Furlong T, O'Donnell PV, Storer BE, McCune JS, Storb R, et al. Posttransplantation cyclophosphamide for prevention of graft-versus-host disease after HLA-matched mobilized blood cell transplantation. Blood. 2016;127:1502-8.

5. Storb R, Deeg HJ, Farewell V, Doney K, Appelbaum F, Beatty P, et al. Marrow transplantation for severe aplastic anemia: methotrexate alone compared with a combination of methotrexate and cyclosporine for prevention of acute graft-versus-host disease. Blood. 1986;68:119-25.

6. Luznik L, Bolaños-Meade J, Zahurak M, Chen AR, Smith BD, Brodsky R, et al. High-dose cyclophosphamide as single-agent, short-course prophylaxis of graft-versus-host disease. Blood. 2010;115:3224-30.

7. Kanakry CG, O'Donnell PV, Furlong $T$, de Lima MJ, Wei $W$, Medeot $M$, et al. Multi-institutional study of post-transplantation cyclophosphamide as single-agent graft-versus-host disease prophylaxis after allogeneic bone marrow transplantation using myeloablative busulfan and fludarabine conditioning. J Clin Oncol. 2014;32:3497-505.

8. Moiseev IS, Pirogova OV, Alyanski AL, Babenko EV, Gindina TL, Darskaya EI, et al. Graft-versus-Host Disease Prophylaxis in Unrelated Peripheral Blood Stem Cell Transplantation with Post-Transplantation Cyclophosphamide, Tacrolimus, and Mycophenolate Mofetil. Biol Blood Marrow Transplant. 2016;22:1037-42.

9. Steering Committee Of The Blood And Marrow Transplant Clinical Trials Network. The Blood and Marrow Transplant Clinical Trials Network: An Effective Infrastructure for Addressing Important Issues in Hematopoietic Cell Transplantation. Biol Blood Marrow Transplant. 2016;22:1747-57.

10. Bolaños-Meade J, Reshef R, Fraser R, Fei M, Abhyankar S, Al-Kadhimi Z, et al. Three prophylaxis regimens (tacrolimus, mycophenolate mofetil, and cyclophosphamide; tacrolimus, methotrexate, and bortezomib; or tacrolimus, methotrexate, and maraviroc) versus tacrolimus and methotrexate for prevention of graft-versus-host disease with haemopoietic cell transplantation with reduced-intensity conditioning: a randomised phase 2 trial with a non-randomised contemporaneous control group (BMT CTN 1203). The Lancet Haematology. 2019;6:e132-43.

11. Carnevale-Schianca F, Caravelli D, Gallo S, Coha V, D'Ambrosio L, Vassallo $E_{1}$ et al. Post-Transplant Cyclophosphamide and Tacrolimus-Mycophenolate Mofetil Combination Prevents Graft-versus-Host Disease in Allogeneic Peripheral Blood Hematopoietic Cell Transplantation from HLA-Matched Donors. Biol Blood Marrow Transplant. 2017;23:459-66.

12. El Fakih $R$, Kotb $A$, Hashmi $S$, Chaudhri $N$, Alsharif $F$, Shaheen $M$, et al. Outcomes of allogeneic hematopoietic cell transplant for acute myeloid leukemia in adolescent patients. Bone Marrow Transplant. 2020;55:182-8.

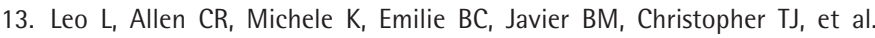
Post-Transplantation High-Dose Cyclophosphamide (Cy) Is Effective Single Agent GVHD Prophylaxis That Permits Prompt Immune Reconstitution after Myeloablative HLA Matched Related and Unrelated Bone Marrow Transplantation (BMT). Blood. 2006;108:2891.

14. Ruggeri A, Labopin M, Bacigalupo A, Afanasyev B, Cornelissen JJ, Elmaagacli A, et al. Post-transplant cyclophosphamide for graft-versus-host disease prophylaxis in HLA matched sibling or matched unrelated donor transplant for patients with acute leukemia, on behalf of ALWP-EBMT. J Hematol Oncol. 2018;11:40. 